\title{
Ambient air pollution and endocrinologic disorders in childhood
}

\author{
You Joung Heo, \\ Hae Soon Kim
}

Department of Pediatrics, Ewha Women's University College of Medicine, Seoul, Korea
Received: 22 June, 2021

Revised: 10 August, 2021

Accepted: 23 August, 2021

Address for correspondence:

Hae Soon Kim

Department of Pediatrics, Ewha Women's University College of Medicine, 260, Gonghang-daero, Gangseo-gu, Seoul 07804, Korea Email: hyesk@ewha.ac.kr https://orcid.org/0000-0002-69766878
Ambient air pollution has been proposed as an important environmental risk factor that increases global mortality and morbidity. Over the past decade, several human and animal studies have reported an association between exposure to air pollution and altered metabolic and endocrine systems in children. However, the results for these studies were mixed and inconclusive and did not demonstrate causality because different outcomes were observed due to different study designs, exposure periods, and methodologies for exposure measurements. Current proposed mechanisms include altered immune response, oxidative stress, neuroinflammation, inadequate placental development, and epigenetic modulation. In this review, we summarized the results of previous pediatric studies that reported effects of prenatal and postnatal air pollution exposure on childhood type 1 diabetes mellitus, obesity, insulin resistance, thyroid dysfunction, and timing of pubertal onset, along with underlying related mechanisms.

\section{Keywords: Air pollution, Endocrinology, Pediatrics}

\section{Highlights}

There is growing evidence for a relationship between ambient air pollution and altered metabolic and endocrine systems in children. Further studies considering multipollutant nature of air pollution and additional outcomes are needed to demonstrate the underlying mechanism.

\section{Introduction}

Exposure to ambient air pollution (AP) increases morbidity and mortality and contributes substantially to the global burden of disease. ${ }^{1)}$ AP increases the risk of respiratory and cardiovascular diseases, strokes, allergic diseases, diabetes, and autoimmune diseases in adults. ${ }^{2-5)}$ AP is generated mainly from fossil fuel combustion, industrial processes, construction work, cigarette smoking, and consumer products and is naturally produced by wildfires, volcanoes, and thunderstorms. ${ }^{6}$ The components of AP are complex and mixed with natural or artificial substances and contain large volumes of gases, liquid droplets, or solid particles. Gaseous components of AP include ozone $\left(\mathrm{O}_{3}\right)$, nitrogen dioxide $\left(\mathrm{NO}_{2}\right)$, sulfur dioxide $\left(\mathrm{SO}_{2}\right)$, carbon monoxide, and carbon dioxide. Particulate matter (PM) includes dust, soil, organic acids, and metals, and some of these compounds have similar effects to endocrine-disrupting chemicals (EDCs). ${ }^{6} \mathrm{PM}$ is categorized based on particle size - $\mathrm{PM}_{10}$ (smaller than $10 \mu \mathrm{m}$ ), PMcoarse (ranging from $2.5 \mu \mathrm{m}$ to $10 \mu \mathrm{m}$ ), $\mathrm{PM}_{2.5}$ (smaller than $2.5 \mu \mathrm{m}$ ), and ultrafine PM (smaller than $0.1 \mu \mathrm{m}$ ). Traffic-related AP contributes significantly to outdoor AP, especially in urban settings, and is comprised of nitrogen oxides $\left(\mathrm{NO}_{\mathrm{x}}\right)$ of nitric oxide $(\mathrm{NO})$ and $\mathrm{NO}_{2}$ and PM. In children, there is growing evidence that AP can affect the endocrine system. In this review, we discussed the effects of ambient APs on childhood endocrinologic 
disorders and possible associated mechanisms.

\section{Association between AP and childhood endocri- nologic disorders in human studies}

\section{Type 1 diabetes mellitus}

Type 1 diabetes mellitus (T1DM) is an autoimmune disease characterized by destruction of insulin-producing pancreatic islet beta cells. The exact etiology is understood incompletely, although disease development is influenced by both genetic and nongenetic factors, including infections, early infant diet, gut microbiome, and vitamin D deficiency. ${ }^{7}$ It recently has been suggested that environmental chemicals and AP are associated with development of T1DM. ${ }^{8)}$ Previous case-control studies of children with T1DM showed a relationship between development of T1DM and concentrations of $\mathrm{O}_{3}{ }^{9)}$ and $\mathrm{PM}_{10}$, especially in children younger than 5 years. ${ }^{10)}$ Research has found that households with diabetes were more likely to be exposed to secondhand smoke than nondiabetic households."

Human studies of the relationship between ambient AP and T1DM in pediatric patients have investigated age at onset, incidence, or disease exacerbation of T1DM (Table 1). Three studies that evaluated the effect of prenatal ambient AP exposure showed inconsistent results. ${ }^{11-13)}$ A Swedish observational

Table 1. Human studies investigating the relationship of ambient air pollution and type 1 diabetes in children

\begin{tabular}{|c|c|c|c|c|c|c|c|}
\hline Country & Study design & Subjects, n (age) & Exposure & $\begin{array}{l}\text { Exposure periods } \\
\text { (age) }\end{array}$ & Outcome (age) & Findings & Study \\
\hline \multicolumn{8}{|l|}{ Prenatal } \\
\hline Sweden & Observational & 84,039 & $\begin{array}{l}\mathrm{NO}_{x}, \mathrm{O}_{3}, \\
\text { traffic density }\end{array}$ & Prenatal & $\begin{array}{l}\text { T1DM incidence } \\
\text { of offspring } \\
\text { (8-14 years old) }\end{array}$ & $\begin{array}{l}\mathrm{O}_{3} \text { during the second trimester } \\
\text { and } \mathrm{NO}_{x} \text { in the third trimester } \\
\text { were associated with increased } \\
\text { T1DM risk among offspring. }\end{array}$ & $\begin{array}{l}\text { Malmqvist, } \\
2015\end{array}$ \\
\hline Canada & Cohort & 754,698 & $\mathrm{NO}_{2}, \mathrm{O}_{3}, \mathrm{PM}_{2.5}$ & Prenatal & $\begin{array}{l}\text { Incidence of } \\
\text { T1DM } \\
\text { (up to } 6 \text { years old) }\end{array}$ & $\begin{array}{l}\mathrm{O}_{3} \text { exposure during the first } \\
\text { trimester of pregnancy } \\
\text { was associated with T1DM } \\
\text { incidence (not } \mathrm{NO}_{2}, \mathrm{PM}_{2.5} \text { ). }\end{array}$ & $\begin{array}{l}\text { Elten, }^{12)} \\
2020\end{array}$ \\
\hline Israel & Case-control & $\begin{array}{l}362 \text { T1DM } \\
\text { patients vs. 3,512 } \\
\text { controls }\end{array}$ & $\begin{array}{l}\mathrm{NO}, \mathrm{NO}_{2}, \mathrm{O}_{3}, \mathrm{SO}_{2}, \\
\mathrm{PM}_{10}, \mathrm{PM}_{2.5}\end{array}$ & Prenatal & $\begin{array}{l}\text { T1DM incidence } \\
\text { of offspring } \\
\text { (0-18 years) }\end{array}$ & $\begin{array}{l}\mathrm{O}_{3} \text { during gestation was } \\
\text { associated with the } \mathrm{T} 1 \mathrm{DM} \text { in } \\
\text { offspring (not } \mathrm{NO}, \mathrm{NO}_{2}, \mathrm{SO}_{2} \text {, } \\
\mathrm{PM}_{10}, \mathrm{PM}_{2.5} \text { ). }\end{array}$ & $\begin{array}{l}\text { Taha- } \\
\text { Khalde, }^{13)} \\
2021\end{array}$ \\
\hline \multicolumn{8}{|l|}{ Postnatal } \\
\hline Germany & Observational & $\begin{array}{l}671 \mathrm{T1DM} \\
\text { patients } \\
\text { (0-20 years old) }\end{array}$ & $\begin{array}{l}\mathrm{NO}_{2,}, \mathrm{PM}_{10,}, \mathrm{PM}_{2.5}, \\
\quad \mathrm{PM} 2.5 \mathrm{abs}\end{array}$ & NA & $\begin{array}{l}\text { Age at onset of } \\
\text { T1DM }\end{array}$ & $\begin{array}{l}\text { Higher exposure to } \mathrm{PM}_{10} \text { and } \\
\mathrm{NO}_{2} \text { accelerates the onset of } \\
\mathrm{T} 1 \mathrm{DM} \text { in } 0-4 \text { years old children } \\
\text { (not } \mathrm{PM}_{2.5}, \mathrm{PM}_{2.5} \text { abs). }\end{array}$ & $\begin{array}{l}\text { Beyerlein, } \\
2015\end{array}$ \\
\hline Italy & Observational & $\begin{array}{c}631,275 \\
(0-14 \text { years old })\end{array}$ & $\mathrm{NO}_{x}, \mathrm{O}_{3}, \mathrm{PM}_{10}, \mathrm{CO}$ & $\begin{array}{l}\text { 5-Year average } \\
\text { levels }\end{array}$ & T1DM incidence & $\begin{array}{l}\text { PM10 was associated with T1DM } \\
\text { incidence rate (not } \mathrm{O}_{3}, \mathrm{NO}_{x_{1}} \\
\text { CO). } \\
\text { Mean age at T1DM onset was } \\
\text { positively associated with } \mathrm{PM}_{10} \\
\text { and inversely with } \mathrm{O}_{3} \text {. }\end{array}$ & $\begin{array}{l}\text { Di Ciaula, } \\
2016\end{array}$ \\
\hline Germany & Observational & $\begin{array}{c}\text { 6,807 T1DM } \\
\text { patients } \\
\text { (0-19 years old) }\end{array}$ & $\mathrm{NO}_{2}, \mathrm{O}_{3}, \mathrm{PM}_{10}$ & $\begin{array}{l}\text { 5-Year average } \\
\text { levels }\end{array}$ & $\begin{array}{l}\text { Age at onset of } \\
\text { T1DM }\end{array}$ & $\begin{array}{l}\text { Not associated with mean age } \\
\text { at diagnosis }\end{array}$ & $\begin{array}{c}\text { Rosenbauer, } \\
2016\end{array}$ \\
\hline Germany & Cross-sectional & $\begin{array}{c}771 \mathrm{T1DM} \\
\text { patients } \\
\text { (11-21 years old) }\end{array}$ & $\mathrm{NO}_{2}, \mathrm{O}_{3}, \mathrm{PM}_{10}$ & $\begin{array}{l}\text { 5-Year average } \\
\quad \text { levels }\end{array}$ & $\begin{array}{l}\text { HbA1c, daily } \\
\text { insulin dose }\end{array}$ & $\begin{array}{l}\text { No adverse effect on metabolic } \\
\text { control }\end{array}$ & $\begin{array}{l}\text { Tamayo, }^{17)} \\
2016\end{array}$ \\
\hline Germany & Cross-sectional & $\begin{array}{c}\text { 37,372 T1DM } \\
\text { patients } \\
\text { (0.5-20 years old) }\end{array}$ & $\mathrm{NO}_{2}, \mathrm{O}_{3}, \mathrm{PM}_{10}$ & $\begin{array}{l}\text { 5-Year average } \\
\text { levels }\end{array}$ & $\begin{array}{l}\text { HbA1c, daily } \\
\text { insulin dose }\end{array}$ & $\begin{array}{l}\text { Inverse relationship between } \mathrm{O}_{3} \\
\text { and } \mathrm{HbA} 1 \mathrm{C}\left(\text { not } \mathrm{NO}_{2}, \mathrm{PM}_{10}\right)\end{array}$ & $\begin{array}{l}\text { Lanzinger, }_{,}^{18)} \\
2018\end{array}$ \\
\hline Canada & Cohort & 754,698 & $\mathrm{NO}_{2}, \mathrm{O}_{3}, \mathrm{PM}_{2.5}$ & $\begin{array}{l}\text { Early childhood } \\
(0-5 \text { years old })\end{array}$ & $\begin{array}{c}\text { Incidence of } \\
\text { T1DM } \\
\text { (up to } 6 \text { years old) }\end{array}$ & $\begin{array}{l}\text { Not associated with T1DM } \\
\text { incidence }\end{array}$ & $\begin{array}{l}\text { Elten, }^{12)} \\
2020\end{array}$ \\
\hline Poland & Observational & $\begin{array}{c}947,362 \\
(0-18 \text { years old })\end{array}$ & $\begin{array}{l}\mathrm{NO}_{2}, \mathrm{NO}_{x}, \mathrm{SO}_{2} \\
\mathrm{PM} \text { 10abs, } \mathrm{CO}\end{array}$ & $\begin{array}{l}\text { 2-Year average } \\
\text { levels }\end{array}$ & $\begin{array}{l}\text { No. of new cases } \\
\text { of T1DM }\end{array}$ & $\begin{array}{l}\mathrm{PM}_{10} \mathrm{abs}, \mathrm{SO}_{2} \text {, and } \mathrm{CO} \text { were } \\
\text { correlated with the number of } \\
\text { new cases of T1DM (not } \mathrm{NO}_{2} \text {, } \\
\mathrm{NO}_{x} \text { ). }\end{array}$ & $\begin{array}{l}\text { Michalska, }{ }_{1}^{19)} \\
2020\end{array}$ \\
\hline
\end{tabular}

T1DM, type 1 diabetes mellitus; $\mathrm{NO}_{2}$, nitrogen dioxide; $\mathrm{PM}_{10}$, particulate matter with an aerodynamic diameter of <10 $\mu$ m; $\mathrm{PM} 2.5$, particulate matter with an aerodynamic diameter of <2.5 $\mu \mathrm{m}$; $\mathrm{PM}_{2.5} \mathrm{abs}$, absorbance of $\mathrm{PM}_{2.5}$; $\mathrm{NA}$, not available; $\mathrm{NO}_{x}$, nitrogen oxide; $\mathrm{O}_{3}$, ozone; $\mathrm{CO}$, carbon monoxide; $\mathrm{HbA} 1 \mathrm{c}$, hemoglobin $\mathrm{A} 1 \mathrm{c}$; $\mathrm{SO}_{2}$, sulfur dioxide; PM1oabs, absorbance of PM10. 
study found that NOx exposure during the third trimester of pregnancy was associated with development of T1DM in children. ${ }^{11)}$ However, in recent studies, exposure to $\mathrm{NO}$ or $\mathrm{NO}_{2}$ had no significant effect on the incidence of T1DM. ${ }^{12,13)}$ Results of the effects of maternal $\mathrm{O}_{3}$ exposure consistently showed that $\mathrm{O}_{3}$ exposure was associated with increased incidence of T1DM in children. ${ }^{11-13)}$ However, the associations between $\mathrm{PM}_{10}{ }^{13)}$ and $\mathrm{PM}_{2.5}$ exposure $^{12,13)}$ during gestation and incidence of T1DM in children were not significant.

Results from postnatal exposure studies that assessed air pollutants were inconsistent. ${ }^{14-19)}$ Most previous studies showed no relationship between exposure to $\mathrm{NO}_{x}$ or $\mathrm{NO}_{2}$ during the postnatal period and incidence, ${ }^{12,15,19)}$ or age at onset ${ }^{16)}$ of T1DM or serum hemoglobin A1c ( $\mathrm{HbAlc}$ ) level among patients with $\mathrm{T} 1 \mathrm{DM},{ }^{17,18)}$ with the exception of one study reporting that greater exposure to $\mathrm{NO}_{2}$ accelerated onset of T1DM in early childhood (0-4 years of age) ${ }^{14)}$ The increased annual mean concentration of $\mathrm{O}_{3}$ during childhood or adolescence accelerated the mean age at onset of $\mathrm{T} 1 \mathrm{DM},{ }^{15)}$ although no direct relationship was observed. ${ }^{16)}$ Other studies reported no association ${ }^{17)}$ or an inverse association ${ }^{18)}$ with serum HbAlc level among patients with T1DM, suggesting a therapeutic

Table 2. Human studies investigating the relationship of ambient air pollution and childhood obesity

\begin{tabular}{|c|c|c|c|c|c|c|c|}
\hline Country & Study design & $\begin{array}{l}\text { Subjects, } \\
\text { n (age) }\end{array}$ & $\begin{array}{c}\text { Exposure } \\
\text { (average levels) }\end{array}$ & $\begin{array}{l}\text { Exposure periods } \\
\text { (age) }\end{array}$ & Outcome (age) & Findings & Study \\
\hline \multicolumn{8}{|l|}{ Prenatal } \\
\hline USA & Cohort & 2,115 & $\begin{array}{l}\mathrm{PM}_{2.5,} \mathrm{BC} \text {, traffic } \\
\text { density, roadway } \\
\text { proximity }\end{array}$ & Third trimester & $\begin{array}{l}\text { Birth weight, } \\
\text { weight gain } 6 \\
\text { months of age }\end{array}$ & $\begin{array}{l}\text { BC exposure, roadway } \\
\text { proximity and traffic } \\
\text { density: associated with } \\
\text { greater weight gain in } \\
\text { infancy (not PM } 2.5)\end{array}$ & Fleisch, 2015 \\
\hline USA & Cohort & 1,418 & $\begin{array}{l}\mathrm{PM}_{2.5,}, \mathrm{BC} \text {, traffic } \\
\text { density, roadway } \\
\text { proximity }\end{array}$ & Third trimester & $\begin{array}{l}\text { BMI, WC, skinfold } \\
\text { thickness, total } \\
\text { and truncal fat } \\
\text { mass }\end{array}$ & $\begin{array}{l}\text { Not associated with } \\
\text { childhood adiposity }\end{array}$ & Fleisch, 2017 \\
\hline USA & Cohort & 1,446 & $\mathrm{PM}_{2.5}$ & Prenatal & $\begin{array}{l}\text { Overweight or } \\
\text { obesity } \\
\text { (2-9 years old) }\end{array}$ & $\begin{array}{l}\text { Increase the risk of childhood } \\
\text { overweight or obesity }\end{array}$ & $\mathrm{Mao}_{1}^{26)} 2017$ \\
\hline USA & Cohort & 239 & $\mathrm{PM}_{2.5}$ & Prenatal & $\begin{array}{l}\text { BMI, fat mass, WC, } \\
\text { WHR, skinfold } \\
\text { thickness } \\
\text { (4 years old) }\end{array}$ & $\begin{array}{l}\text { Higher PM2.5 exposure in } \\
\text { mild-pregnancy was } \\
\text { associated with increased } \\
\text { fat mass and higher BMI } \\
\text { among boys. } \\
\text { Higher PM2.5 exposure from } \\
\text { early-to-mid pregnancy } \\
\text { was associated with WHR } \\
\text { among girls. }\end{array}$ & $\mathrm{Chiu}_{1}^{27)} 2017$ \\
\hline USA & Cohort & 2,318 & $\mathrm{NOx}, \mathrm{PM}_{2.5}$ & In utero & $\begin{array}{l}\text { 4-Year BMI } \\
\text { trajectory and BMI } \\
\text { at } 10 \text { years old }\end{array}$ & $\begin{array}{l}\text { Not associated with BMI } \\
\text { at age } 10 \text { and the rate of } \\
\text { growth over 4-year follow- } \\
\text { up }\end{array}$ & $\mathrm{Kim}_{1}^{28)} 2018$ \\
\hline USA & Cohort & 1,649 & $\begin{array}{l}\text { PM2.5, BC, traffic } \\
\text { density }\end{array}$ & Prenatal & $\begin{array}{l}\text { BMI trajectory } \\
(0.5-10 \text { years old })\end{array}$ & $\begin{array}{l}\text { Not associated with } \\
\text { childhood BMI trajectory }\end{array}$ & Fleisch, $^{29)} 2018$ \\
\hline Hong Kong & Cohort & 8,298 & $\begin{array}{l}\mathrm{NO}, \mathrm{NO}_{2}, \mathrm{SO}_{2} \\
\mathrm{PM} 10\end{array}$ & In utero & $\begin{array}{l}\operatorname{BMI}(9,11,13 \text {, and } \\
15 \text { years old })\end{array}$ & $\begin{array}{l}\text { Higher } \mathrm{SO}_{2} \text { in utero was } \\
\text { associated with lower BMI } \\
\text { at } 13 \text { and } 15 \text { years }\end{array}$ & Huang, ${ }^{30)} 2019$ \\
\hline \multicolumn{8}{|l|}{ Postnatal } \\
\hline USA & Cohort & $\begin{array}{c}2,889 \\
\text { (9-10 years old) }\end{array}$ & Traffic density & $\begin{array}{l}\text { 8-Year average } \\
\text { volume }\end{array}$ & BMI (18 years old) & $\begin{array}{l}\text { Positive association with } \\
\text { attained BMl at age } 18\end{array}$ & Jerrett, 2010 \\
\hline USA & Cohort & $\begin{array}{c}4,550 \\
\text { (5-7 years old) }\end{array}$ & $\begin{array}{l}\mathrm{NO}_{x_{1}} \text { Traffic } \\
\text { density }\end{array}$ & $\begin{array}{l}\text { 1-Year average } \\
\text { levels }\end{array}$ & $\begin{array}{l}\text { BMl growth } \\
\text { (10 years old) }\end{array}$ & $\begin{array}{l}\text { NOx (nonfreeway) was } \\
\text { associated with BMI at age } \\
10 \text { and the rate of growth } \\
\text { over 5-year follow-up }\end{array}$ & Jerrett, ${ }^{32)} 2014$ \\
\hline China & Cross-sectional & 30,056 & $\mathrm{NO}_{2}, \mathrm{O}_{3}, \mathrm{SO}_{2}, \mathrm{PM}_{10}$ & $\begin{array}{l}\text { 3-Year average } \\
\text { levels }\end{array}$ & $\begin{array}{l}\text { Overweight and } \\
\text { obesity } \\
\text { (2-14 years old) }\end{array}$ & $\begin{array}{l}\text { Positive association with } \\
\text { overweight and obesity }\end{array}$ & Dong, $^{35)} 2014$ \\
\hline USA & Cohort & $\begin{array}{c}3,318 \\
(10 \text { years old })\end{array}$ & $\mathrm{NO}_{x}$ & $\begin{array}{l}\text { 8-Year average } \\
\text { levels }\end{array}$ & $\begin{array}{l}\text { BMl growth } \\
\text { (18 years old) }\end{array}$ & $\begin{array}{l}\text { Associated with an larger } \\
\text { increase in BMl from age } 10 \\
\text { to } 18 \text { and a higher attained } \\
\text { BMl at age } 18\end{array}$ & $\begin{array}{l}\text { McConnell, } \\
2015\end{array}$ \\
\hline
\end{tabular}


Table 2. (continued)

\begin{tabular}{|c|c|c|c|c|c|c|c|}
\hline Country & Study design & $\begin{array}{c}\text { Subjects, } \\
\text { n (age) }\end{array}$ & $\begin{array}{c}\text { Exposure } \\
\text { (average levels) }\end{array}$ & $\begin{array}{l}\text { Exposure periods } \\
\text { (age) }\end{array}$ & Outcome (age) & Findings & Study \\
\hline USA & Cohort & 1,418 & $\begin{array}{l}\mathrm{PM}_{2.5}, \mathrm{BC} \text {, traffic } \\
\text { density, roadway } \\
\text { proximity }\end{array}$ & $\begin{array}{l}\text { At birth, } \\
\text { early-and } \\
\text { midchildhood } \\
\text { (median } 3.3 \text { and } \\
7.7 \text { years of age) }\end{array}$ & $\begin{array}{l}\text { BMI, WC, skinfold } \\
\text { thickness, total } \\
\text { and truncal fat } \\
\text { mass }\end{array}$ & $\begin{array}{l}\text { Roadway proximity at } \\
\text { birth was associated } \\
\text { with greater BMI, WC and } \\
\text { skinfold thickness in early } \\
\text { childhood and greater } \\
\text { BMI, total and truncal fat } \\
\text { mass in mid childhood (not } \\
\text { traffic density BC, PM } 2.5 \text {. } \\
\text { PM2.5 during the year prior } \\
\text { to visit was negatively } \\
\text { associated with BMI (not } \\
\text { traffic density and BC). }\end{array}$ & Fleisch, 2017 \\
\hline USA & Cohort & 1,446 & $\mathrm{PM}_{2.5}$ & $\begin{array}{l}\text { During first 2-year } \\
\text { of age }\end{array}$ & $\begin{array}{l}\text { Overweight or } \\
\text { obesity } \\
\text { (2-9 years old) }\end{array}$ & $\begin{array}{l}\text { Increase the risk of childhood } \\
\text { overweight or obesity }\end{array}$ & $\mathrm{Mao}^{26)} 2017$ \\
\hline USA & Cross-sectional & $\begin{array}{l}314 \\
\text { overweight or } \\
\text { obese children } \\
\text { (8-15 years old) }\end{array}$ & $\mathrm{NO}_{2}, \mathrm{PM}_{2.5}$ & $\begin{array}{l}\text { 1-Year average } \\
\text { levels prior to visit }\end{array}$ & $\begin{array}{l}\text { BMI, SAAT and } \\
\text { IAAT } \\
\text { (at } 18 \text { years old) }\end{array}$ & $\begin{array}{l}\text { Higher } \mathrm{NO}_{2} \text { and } \mathrm{PM}_{2.5} \text { were } \\
\text { associated with higher } \\
\text { BMI, body fat percent, and } \\
\text { central adiposity. }\end{array}$ & $\begin{array}{l}\text { Alderete, }^{34)} \\
2017\end{array}$ \\
\hline USA & Cohort & 2,318 & $\mathrm{NO}_{x}, \mathrm{PM}_{2.5}$ & $\begin{array}{l}\text { In infancy }(<1) \\
\text { and childhood }\end{array}$ & $\begin{array}{l}\text { 4-Year BMI } \\
\text { trajectory and BMI } \\
\text { at } 10 \text { years old }\end{array}$ & $\begin{array}{l}\text { NOx exposure in infancy } \\
\text { from freeway was } \\
\text { associated with BMI at age } \\
10 \text { and the rate of growth } \\
\text { over 4-year follow-up (not } \\
\text { PM2.5) }\end{array}$ & $\mathrm{Kim}_{1}{ }^{28)} 2018$ \\
\hline Italy & Cohort & 719 & $\begin{array}{l}\mathrm{NO}_{2,} \mathrm{NO}_{x}, \mathrm{PM}_{10,} \\
\mathrm{PM}_{2.5}, \mathrm{PM}_{2.5 \mathrm{abs}} \\
\text { PMcoarse, traffic } \\
\text { density }\end{array}$ & $\begin{array}{l}\text { At birth, } 4 \text { and } 8 \\
\text { years old }\end{array}$ & $\begin{array}{c}\text { BMI, WC, WHR } \\
\text { (4 and } 8 \text { years old) }\end{array}$ & $\begin{array}{l}\text { Not associated with obesity- } \\
\text { related parameters }\end{array}$ & $\begin{array}{l}\text { Fioravanti, } \\
2018\end{array}$ \\
\hline Hong Kong & Cohort & 8,298 & $\begin{array}{l}\mathrm{NO}, \mathrm{NO}_{2}, \mathrm{SO}_{2} \\
\mathrm{PM}_{10}\end{array}$ & $\begin{array}{l}\text { In infancy and } \\
\text { childhood }\end{array}$ & $\begin{array}{l}\text { BMI }(9,11,13 \text {, and } \\
15 \text { years old })\end{array}$ & $\begin{array}{l}\text { Higher } \mathrm{SO}_{2} \text { in childhood } \\
\text { were associated with lower } \\
\text { BMl at } 15 \text { years. } \\
\text { Higher } \mathrm{NO}_{2} \text { childhood was } \\
\text { associated with higher BMI } \\
\text { at } 9,13,15 \text { years among } \\
\text { boys. }\end{array}$ & $\begin{array}{l}\text { Huang, }_{1}^{30)} \\
2019\end{array}$ \\
\hline Netherlands & Cohort & 3,680 & $\begin{array}{l}\mathrm{NO}_{2,}, \mathrm{PM}_{10,}, \mathrm{PM}_{2.5,} \\
\mathrm{PM}_{2.5 \mathrm{abs}}\end{array}$ & $\begin{array}{l}\text { 1-Year average } \\
\text { levels of } 3 \text { periods } \\
\text { of } 2 \text { weeks }\end{array}$ & $\begin{array}{l}\text { Overweight } \\
\text { (3-17 years old) }\end{array}$ & $\begin{array}{l}\mathrm{NO}_{2} \text { exposure increase the } \\
\text { risk of being overweight (not } \\
\text { PM } M_{2.5}, \mathrm{PM}_{10} \text { ). }\end{array}$ & $\begin{array}{c}\text { Bloemsma, } \\
2019\end{array}$ \\
\hline Spain & Cross-sectional & $\begin{array}{l}2,660(7-10 \\
\text { years old })\end{array}$ & $\begin{array}{l}\mathrm{NO}_{2,}, \mathrm{PM}_{2.5}, \mathrm{BC} \\
\text { Ultrafine particles }\end{array}$ & $\begin{array}{l}\text { 1-Week level } \\
\text { during warm and } \\
\text { cold seasons }\end{array}$ & $\begin{array}{l}\text { Overweight or } \\
\text { obesity }\end{array}$ & $\begin{array}{c}\text { Increase the risk of being } \\
\text { overweight or obesity }\end{array}$ & $\begin{array}{l}\text { De Bont, } \\
2019\end{array}$ \\
\hline China & Cross-sectional & $\begin{array}{l}41,439(6-17 \\
\text { years old })\end{array}$ & $\mathrm{PM}_{2.5}$ & $\begin{array}{l}\text { 5-Year average } \\
\text { level }\end{array}$ & Obesity & Increase the risk of obesity & $\begin{array}{l}\text { Guo, } \\
2020\end{array}$ \\
\hline China & Cross-sectional & $\begin{array}{l}36,456(9-17 \\
\text { years old })\end{array}$ & $\begin{array}{l}\mathrm{NO}_{2}, \mathrm{O}_{3}, \mathrm{PM}_{10} \\
\quad \mathrm{PM}_{2.5}\end{array}$ & $\begin{array}{l}\text { 3-Year average } \\
\text { levels }\end{array}$ & Obesity & $\begin{array}{l}\text { Higher } \mathrm{PM}_{2.5}, \mathrm{NO}_{2} \text {, and } \mathrm{O}_{3} \\
\text { exposure increased the risk } \\
\text { of being obesity (not } \mathrm{PM}_{10} \text { ). }\end{array}$ & $\begin{array}{l}\text { Zheng, }_{1}^{39)} \\
2021\end{array}$ \\
\hline China & Cross-sectional & $\begin{array}{l}44,718(7-18 \\
\text { years old })\end{array}$ & $\begin{array}{l}\mathrm{NO}_{2}, \mathrm{PM}_{1}, \mathrm{PM}_{2.5} \\
\mathrm{PM}_{10}\end{array}$ & $\begin{array}{l}\text { 1-Year average } \\
\text { level }\end{array}$ & $\begin{array}{l}\text { BMI, WC, WHR, } \\
\text { general and } \\
\text { central obesity }\end{array}$ & $\begin{array}{l}\text { Associated with obesity- } \\
\text { related parameters }\end{array}$ & $\begin{array}{c}\text { Zhang, }^{40)} \\
2021\end{array}$ \\
\hline Spain & Longitudinal & 416,955 & $\begin{array}{l}\mathrm{NO}^{2}, \mathrm{PM}^{10}, \mathrm{PM}^{2.5} \\
\mathrm{PM}_{\text {coarse }}\end{array}$ & $\begin{array}{l}\text { 1-Year average } \\
\text { level }(2-5 \text { years } \\
\text { old })\end{array}$ & $\begin{array}{l}\text { Overweight or } \\
\text { obesity ( } 15 \text { years } \\
\text { old) }\end{array}$ & $\begin{array}{c}\text { Increase the risk of } \\
\text { developing overweight and } \\
\text { obesity }\end{array}$ & $\begin{array}{l}\text { De Bont, }{ }^{41)} \\
2021\end{array}$ \\
\hline
\end{tabular}

BMI, body mass index; $\mathrm{NO}_{x}$, nitrogen oxide; $\mathrm{NO}_{2}$, nitrogen dioxide; $\mathrm{O}_{3}$, ozone; $\mathrm{SO}_{2}$, sulfur dioxide; $\mathrm{PM} \mathrm{M}_{10}$, particulate matter with an aerodynamic diameter of $<10 \mu \mathrm{m}$; PM2.5, particulate matter with an aerodynamic diameter of <2.5 $\mu$ m; BC, black carbon; WC, waist circumference; SAAT, subcutaneous abdominal adipose tissue; IAAT, intra-abdominal adipose tissue; WHR, waist-to-hip ratio; PM2.5abs, absorbance of PM2.5; PMcoarse, coarse particles have an aerodynamic diameter ranging from 2.5 to $10 \mu \mathrm{m}$ PM1, particulate matter with an aerodynamic diameter of $<1 \mu \mathrm{m}$. 
effect of $\mathrm{O}_{3}$ through blood glucose reduction, because moderate oxidative stress induced by $\mathrm{O}_{3}$ activated both free antioxidants and antioxidative enzymes. ${ }^{20)}$ Postnatal $\mathrm{PM}_{10}$ exposure was associated with the increased incidence of T1DM in children. ${ }^{15,19)}$ The effect on mean age at onset of T1DM of $\mathrm{PM}_{10}$ exposure varied from no association ${ }^{16)}$ to younger ${ }^{14)}$ or older. ${ }^{15)}$ The annual mean concentration of $\mathrm{PM}_{10}$ was not related to serum $\mathrm{HbAlc}$ level in patients with T1DM. ${ }^{17,18)}$ Further, $\mathrm{PM}_{2.5}$ exposure was not related to the incidence of $\mathrm{T}_{1} \mathrm{DM}^{12)}$ or the age of onset in patients with T1DM. ${ }^{14)}$

\section{Childhood obesity}

Childhood obesity can be promoted by multiple factors, primarily due to an imbalance between energy intake and consumption. There is growing evidence that environmental chemical exposure can act as an "obesogen" and contribute to excessive weight gain. ${ }^{21)}$ Previous studies revealed that maternal exposure to combustion-derived polycyclic aromatic hydrocarbons ${ }^{22)}$ and cigarette smoke during pregnancy ${ }^{23)}$ was associated with an increased risk of childhood obesity.

To date, results from human epidemiological studies on the relationship between ambient $\mathrm{AP}$ and childhood obesity have been mixed and inconclusive (Table 2). Further, the results of research on the effects of prenatal exposure to ambient AP on infant or child weight gain were inconsistent. ${ }^{24-30)} \mathrm{PM}_{2.5}$ exposure during gestation was not associated with weight gain in infancy ${ }^{24)}$ or adiposity ${ }^{25,30)}$ or body mass index (BMI) trajector ${ }^{28,29)}$ during early- or midchildhood; however, a positive association between prenatal $\mathrm{PM}_{2.5}$ exposure and childhood overweight or obesity ${ }^{26)}$ or adiposity ${ }^{27)}$ was reported. While most previous studies have set the specific exposure time and investigated the impact of the average concentration during that period, one cohort study used Bayesian distributed lag interaction models to identify prenatal periods that could be sensitive windows influencing childhood obesity by sex. ${ }^{27)}$ This research suggested that increased exposure to $\mathrm{PM}_{2.5}$ in midpregnancy was associated with increased fat mass and higher BMI $z$-score (body size) among boys, and higher exposure to $\mathrm{PM}_{2.5}$ from early-to-mid pregnancy was associated with increased waist-to-hip ratio (body shape). Moreover, another cohort study simultaneously assessed the impact of 4 air pollutants $\left(\mathrm{PM}_{10}, \mathrm{SO}_{2}, \mathrm{NO}\right.$, and $\left.\mathrm{NO}_{2}\right)$ during prenatal and postnatal periods using a multipollutant model to account for collinearity between pollutants and exposure periods and showed that higher $\mathrm{SO}_{2}$ in utero and in childhood was associated with lower BMI, while higher $\mathrm{NO}_{2}$ in childhood was associated with higher BMI among boys. ${ }^{30)}$

Different studies have shown a significant association between postnatal exposure to ambient AP and $\mathrm{BMI}^{25,28,30-34)}$ and the risk for becoming overweight and obese, ${ }^{26,35-41)}$ while no relationship with $\mathrm{BMI}^{42)}$ or a negative association with BMI or obesity-related parameters ${ }^{25,30}$ has been reported. Longitudinal U.S. cohort studies have shown a positive association between higher traffic density within $150 \mathrm{~m}$ around a residence and BMI at 18 years of age, ${ }^{31)}$ although the perimeter was not associated with early- and mildchildhood obesity-related parameters. ${ }^{25,42)}$ Most studies have shown a positive relationship between postnatal $\mathrm{NO}_{\mathrm{x}}$ or $\mathrm{NO}_{2}$ exposure and obesity-related parameters and reported a greater increase in $\mathrm{BMI}^{28,30,32-34)}$ and attained $\mathrm{BMI}$ at 10 years $^{28,32)}$ and 18 years ${ }^{33)}$ of age and a higher risk of being overweight or obese, ${ }^{35-37,39-41)}$ although an Italian cohort study did not report any significant results. ${ }^{42)}$

In regard to $\mathrm{O}_{3}$ exposure, a positive association with overweight or obesity was reported in 2 Chinese cross-sectional studies. ${ }^{35,39)} \mathrm{PM}_{10}$ exposure was positively associated with risk of being overweight or obese in childhood in some studies, ${ }^{35,39,41)}$ but no relationship was found between $\mathrm{PM}_{10}$ exposure and obesity-related parameters or the risk of being overweight or obese during childhood in other studies. ${ }^{30,36,39,42)}$ Effects of postnatal $\mathrm{PM}_{2.5}$ exposure were associated with a higher $\mathrm{BMI}^{34,40)}$ or risk of being overweight or obese ${ }^{37,38,41}$; however a negative ${ }^{25)}$ or no association ${ }^{36,42)}$ with obesity-related parameters also was observed. Several studies have shown a sex difference ${ }^{27)}$ or a strong association between ambient AP and obesity in boys compared with girls, ${ }^{30,39,40)}$ which might be linked to sex differences in biological responses to environmental chemicals and social and behavioral factors. Recent cross-sectional studies showed a significant association of increased risk of obesity in school-aged children by measuring exposure to ambient AP based on the nearest air monitoring station at school instead of home, where children spend most of their time. ${ }^{37-40)}$

\section{Insulin resistance}

An increase in the prevalence of type 2 diabetes mellitus (T2DM) is a global concern for mortality and disability in adults. ${ }^{43)}$ In addition to traditional risk factors such as poor diet, low physical activity, and socioeconomic status, recent studies have suggested that ambient AP exposure can contribute to T2DM development. Although several systematic reviews and meta-analyses have revealed a relationship between ambient $\mathrm{AP}$ exposure and T2DM risk in adults, ${ }^{44-47)}$ no reports have assessed the risk of T2DM due to ambient AP exposure in children. Several studies have evaluated the effects of AP and the association with diabetes development in children and insulin resistance.

Three reports investigating the effect of prenatal exposure to ambient $\mathrm{AP}$ on insulin resistance showed inconsistent results (Table 3). ${ }^{48-50)}$ Prenatal exposure to $\mathrm{NO}_{2}$ was not associated with cord plasma insulin level in infants ${ }^{48}$ ) which might be a risk factor of metabolic disease later in life. However, the exposure paradoxically was associated with fasting glucose, insulin, and homeostatic model assessment for insulin resistance (HOMAIR) in adolescents between $10-15$ years of age. ${ }^{50)}$ Higher prenatal $\mathrm{PM}_{2.5}$ and $\mathrm{PM}_{10}$ exposures were associated with increased cord plasma insulin level, ${ }^{48}$ and prenatal and perinatal $\mathrm{PM}_{2.5}$ exposure was associated with an annual increase in serum HbAlc level in girls from 4-5 years to 6-7 years of age. ${ }^{49)}$ These 2 studies commonly reported that the second trimester of 
Table 3. Human studies investigating the relationship of ambient air pollution and insulin resistance

\begin{tabular}{|c|c|c|c|c|c|c|c|}
\hline Country & Study design & Subjects, n & $\begin{array}{c}\text { Exposure } \\
\text { (average levels) }\end{array}$ & $\begin{array}{c}\text { Exposure periods } \\
\text { (age) }\end{array}$ & Outcome (age) & Findings & Study \\
\hline \multicolumn{8}{|l|}{ Prenatal } \\
\hline Belgium & Observational & $\begin{array}{l}590 \text { Mother-child } \\
\text { pairs }\end{array}$ & $\mathrm{NO}_{2}, \mathrm{PM}_{10}, \mathrm{PM}_{2.5}$ & Prenatal & $\begin{array}{l}\text { Cord plasma } \\
\text { insulin level }\end{array}$ & $\begin{array}{l}\text { Higher } \mathrm{PM}_{2.5} \text { and } \mathrm{PM}_{10} \text { was } \\
\text { associated with increased } \\
\text { cord plasma insulin levels } \\
\text { (not } \mathrm{NO}_{2} \text { ). }\end{array}$ & $\begin{array}{c}\text { Madhloun, } \\
2017\end{array}$ \\
\hline Mexico & Observational & $\begin{array}{l}365 \text { Mother-child } \\
\text { pairs }\end{array}$ & $\mathrm{PM}_{2.5}$ & $\begin{array}{l}\text { From } 4 \text { weeks } \\
\text { prior to LMP to } 52 \\
\text { weeks after) }\end{array}$ & $\begin{array}{l}\text { HbA1c (4-7 years } \\
\text { old) }\end{array}$ & $\begin{array}{l}\text { Associated with an annual } \\
\text { increase in HbA1c in girls } \\
\text { from age } 4-5 \text { years to 6-7 } \\
\text { years. }\end{array}$ & $\begin{array}{l}\text { Moody, }^{49)} \\
2019\end{array}$ \\
\hline Denmark & Cohort & 629 & $\mathrm{NO}_{2}$ & $\begin{array}{l}\text { Prenatal and } \\
\text { postnatal (birth to } \\
\text { age } 7 \text { ) }\end{array}$ & $\begin{array}{l}\text { Fasting glucose, } \\
\text { insulin, HOMA-IR } \\
\text { (10-15 years old) }\end{array}$ & $\begin{array}{l}\text { Inversely associated with } \\
\text { fasting glucose, insulin, } \\
\text { and HOMA-IR }\end{array}$ & $\begin{array}{l}\text { Pedersen, } \\
2019\end{array}$ \\
\hline \multicolumn{8}{|c|}{ 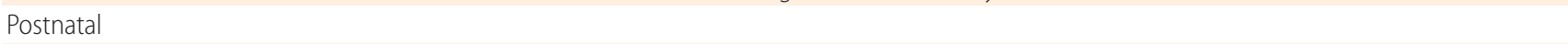 } \\
\hline Germany & Cross-sectional & 397 & $\begin{array}{l}\mathrm{NO}_{2}, \mathrm{PM}_{10}, \mathrm{PM}_{2.5} \\
\text { PM2.5abs, roadway } \\
\text { proximity }\end{array}$ & $\begin{array}{l}\text { 1-Year average } \\
\text { levels of } 3 \text { periods } \\
\text { for } 2 \text { weeks }\end{array}$ & $\begin{array}{l}\text { HOMA-IR (at } 10 \\
\text { years old) }\end{array}$ & $\begin{array}{l}\text { Exposure to } \mathrm{NO}_{2}, \mathrm{PM}_{10} \\
\text { and roadway proximity } \\
\text { increase the HOMA-IR (not } \\
\text { PM2.5, } \mathrm{PM} 2.5 \mathrm{abs} \text { ). }\end{array}$ & $\begin{array}{l}\text { Thiering, } 51) \\
2013\end{array}$ \\
\hline Germanry & Cross-sectional & 837 & $\begin{array}{l}\mathrm{NO}_{2}, \mathrm{PM}_{10}, \mathrm{PM}_{2.5}, \\
\quad \mathrm{PM}_{2.5 \mathrm{abs}}\end{array}$ & $\begin{array}{l}3 \text { to 5-year } \\
\text { average level }\end{array}$ & $\begin{array}{l}\text { HOMA-IR (at } 15 \\
\text { years old) }\end{array}$ & $\begin{array}{l}\text { Exposure to } \mathrm{NO}_{2}, \mathrm{PM}_{10} \\
\text { increase the } \mathrm{HOMA}-\mathrm{IR} \text { (not } \\
\mathrm{PM}_{2.5}, \mathrm{PM}_{2.5} \mathrm{abs} \text { ). }\end{array}$ & $\begin{array}{l}\text { Thiering, } \\
2016\end{array}$ \\
\hline USA & Cohort & 1,418 & $\begin{array}{l}\mathrm{PM}_{2.5}, \mathrm{BC} \text {, traffic } \\
\text { density, roadway } \\
\text { proximity }\end{array}$ & $\begin{array}{l}\text { 3rd trimester, } \\
\text { at birth, } \\
\text { midchildhood } \\
\text { (median } 7.7 \text { years } \\
\text { of age) }\end{array}$ & $\begin{array}{l}\text { HOMA-IR at } \\
\text { midchildhood } \\
\text { (median age } 7.7 \\
\text { years) }\end{array}$ & $\begin{array}{l}\text { PM2.5 exposure during the } \\
\text { year prior to visit, traffic } \\
\text { density and roadway } \\
\text { proximity at birth were } \\
\text { negatively associated with } \\
\text { HOMA-IR. }\end{array}$ & $\begin{array}{l}\text { Fleisch, } \\
2017\end{array}$ \\
\hline USA & Cohort & $\begin{array}{l}314 \text { Overweight } \\
\text { or obese children }\end{array}$ & $\mathrm{NO}_{2}, \mathrm{PM}_{2.5}$ & $\begin{array}{c}\text { 1-Year average } \\
\text { level }\end{array}$ & $\begin{array}{l}\text { Results of FSIVGTT } \\
\text { test (during } \\
\text { follow-up and at } \\
18 \text { years old) }\end{array}$ & $\begin{array}{l}\text { Associated with a faster } \\
\text { decline in insulin } \\
\text { sensitivity and a lower } \\
\text { insulin sensitivity at age } \\
18 \text { years }\end{array}$ & $\begin{array}{l}\text { Alderete, }^{34)} \\
2017\end{array}$ \\
\hline USA & Cross-sectional & $\begin{array}{l}429 \text { Overweight } \\
\text { or obese children }\end{array}$ & $\mathrm{NO}_{2}, \mathrm{NO}_{x}, \mathrm{O}_{3}, \mathrm{PM}_{2.5}$ & $\begin{array}{l}\text { 1-Year average } \\
\text { level }\end{array}$ & $\begin{array}{c}\text { Results of FSIVGTT } \\
\text { test } \\
\text { (8-18 years old) }\end{array}$ & $\begin{array}{l}\mathrm{PM}_{2.5} \mathrm{NO}_{2} \text {, and } \mathrm{NO}_{x} \text { was } \\
\text { associated with higher } \\
\text { fasting insulin, glucose, } \\
\text { acute insulin response to } \\
\text { glucose and lower insulin } \\
\text { sensitivity (not } \mathrm{O}_{3} \text { ). }\end{array}$ & $\begin{array}{c}\text { Toledo-Corral, }^{53)} \\
2018\end{array}$ \\
\hline USA & Prospective & $\begin{array}{l}75 \text { Obese } \\
\text { adolescents }\end{array}$ & $\begin{array}{l}\mathrm{NO}_{2}, \mathrm{O}_{3}, \mathrm{PM}_{2.5} \\
\text { roadway } \\
\text { proximity }\end{array}$ & $\begin{array}{l}\text { 2-Year average } \\
\text { levels }\end{array}$ & $\begin{array}{c}\mathrm{HbA1c} \\
\text { (postsurgery) }\end{array}$ & $\begin{array}{l}\mathrm{NO}_{2} \text { was associated with } \\
\text { less improvement in } \\
\text { HbA1c (not } \mathrm{PM}_{2.5} \text { ). }\end{array}$ & $\begin{array}{c}\text { Ghosh, }^{55)} \\
2018\end{array}$ \\
\hline Denmark & Cohort & 629 & $\mathrm{NO}_{2}$ & Birth to age 7 & $\begin{array}{l}\text { Fasting glucose, } \\
\text { insulin, HOMA-IR } \\
\text { (10-15 years old) }\end{array}$ & $\begin{array}{l}\text { Inversely associated with } \\
\text { fasting glucose, insulin, } \\
\text { and HOMA-IR }\end{array}$ & $\begin{array}{l}\text { Pedersen, } \\
2019\end{array}$ \\
\hline China & Cross-sectional & 9,897 & $\begin{array}{c}\mathrm{NO}_{2}, \mathrm{PM}_{10}, \mathrm{PM}_{1} \\
\mathrm{PM}_{2.5}\end{array}$ & $\begin{array}{c}\text { 2-Year average } \\
\text { levels }\end{array}$ & $\begin{array}{l}\text { Fasting glucose } \\
\text { (10-18 years old })\end{array}$ & $\begin{array}{l}\mathrm{PM}_{1} \text { and } \mathrm{NO}_{2} \text { exposures } \\
\text { were associated with } \\
\text { elevated fasting blood } \\
\text { glucose (not } \mathrm{PM}_{10} \text { ). }\end{array}$ & $\begin{array}{l}\text { Zhang, }_{1}^{54)} \\
2021\end{array}$ \\
\hline
\end{tabular}

$\mathrm{NO}_{2}$, nitrogen dioxide; $\mathrm{PM}_{10}$, particulate matter with an aerodynamic diameter of <10 $\mu \mathrm{m} ; \mathrm{PM}_{2.5}$, particulate matter with an aerodynamic diameter of <2.5 $\mu$ m; PM2.5abs, absorbance of PM2.5; HOMA-IR, homeostatic model assessment for insulin resistance; PM1, particulate matter with an aerodynamic diameter of $<1 \mu \mathrm{m}$; BC, black carbon; FSIVGTT, frequently sampled intravenous glucose tolerance test; $\mathrm{O}_{3}$, ozone; HbA1c, hemoglobin A1c; LMP, last menstrual period.

pregnancy was an exposure window associated with increased serum HbAlc level later in childhood.

Most previous studies have reported a positive association of higher rates of exposure to $\mathrm{NO}_{2}$ during childhood and adolescence with increased HOMA-IR ${ }^{51,52)}$ or insulin resistance ${ }^{34,53)}$ and increased fasting glucose level, ${ }^{53,54)}$ with the exception of one report that showed a negative association. ${ }^{50)}$ Exposure to $\mathrm{PM}_{10}$ was associated with increased HOMA-IR in 2 German studies, ${ }^{51,52)}$ although exposure was not associated with fasting glucose level in a Chinese study. ${ }^{54)}$ Results from studies on exposure to $\mathrm{PM}_{2.5}$ have ranged from negative ${ }^{25)}$ or no relationship with HOMA-IR, ${ }^{51,52)}$ to a positive association 
with lower insulin sensitivity. ${ }^{53)}$ Two studies in the United States that included overweight or obese children used the frequently sampled intravenous glucose tolerance test and revealed that higher $\mathrm{NO}_{2}$ and $\mathrm{PM}^{2.5}$ were associated with higher insulin resistance and secretion, as measured by higher glycemic values, ${ }^{34,53)}$ and a faster decline in insulin sensitivity during follow-up, independent of adiposity. ${ }^{34)}$ These findings suggest that increased AP exposure is an independent risk factor for $\beta$-cell exhaustion. Only one intervention and prospective study was conducted in adolescents who underwent laparoscopic adjustable gastric banding due to severe obesity. That study found that increased exposure to $\mathrm{NO}_{2}$ attenuated the magnitude of $\mathrm{HbAlc}$ reduction, a known metabolic benefit of gastric banding. ${ }^{55)}$

\section{Thyroid dysfunction}

Several environmental chemicals have structures similar to those of thyroid hormones. These chemicals include polychlorinated biphenyls, triclosan, polybrominated diphenyl ethers, and bisphenol A and can reduce circulating levels of thyroid hormone by interfering with thyroid hormone metabolism, transport, and clearance. ${ }^{56)}$ Findings from previous studies suggest that airborne persistent organic pollutants, ${ }^{57)}$ cadmium ${ }^{58)}$ and exposure to active and passive cigarette smoke ${ }^{59)} \mathrm{can}$ affect thyroid hormone regulation and function in neonates and adults.

A few human studies on the impact of PM pollution exposure on thyroid function have been conducted, although these studies have focused on the relationship between maternal exposure and neonatal thyroid function (Table 4). ${ }^{60-63)}$ Maternal exposure to $\mathrm{PM}_{2.5}$ in the third trimester was inversely associated with cord blood thyroid-stimulating hormone (TSH) level and the free thyroxine (T4)/free triiodothyronine (T3) ratio and was positively associated with cord blood free $\mathrm{T} 3,{ }^{60)}$ but no association between maternal $\mathrm{PM}_{2.5}$ exposure in the first trimester and neonatal TSH level was found. ${ }^{62)}$ These 2 studies identified cord blood free $\mathrm{T}^{60)}$ and maternal free $\mathrm{T} 4$ in the second trimester ${ }^{62)}$ as a partial mediator that linked prenatal $\mathrm{PM}_{2.5}$ exposure and birth weight of newborns. Another study evaluated the susceptible prenatal window period in which $\mathrm{PM}_{2.5}$ exposure at the end of the first trimester and $\mathrm{PM}_{10}$ exposure throughout most of the pregnancy were associated with higher total newborn T4 concentration in heel-prick blood spot test. ${ }^{61)}$ A cross-sectional study in China showed that high $\mathrm{PM}_{2.5}$ exposure during pregnancy was associated with increased incidence of congenital hypothyroidism in offspring. ${ }^{63)}$ However, no studies have investigated the association between postnatal PM exposure and thyroid function in childhood or adolescence.

\section{Pubertal development}

Adiposity and exposure to EDCs have been suggested as important factors in the association between environmental factors and pubertal onset, particularly with respect to the current decline in the average age at onset of puberty in girls. ${ }^{64)}$ For example, early life tobacco exposure ${ }^{65}$ or secondhand and prenatal smoke exposure ${ }^{66)}$ is associated with earlier pubertal maturation.

A few epidemiological studies investigating AP and pubertal development in children have shown inconsistent results (Table 5). ${ }^{67-70)}$ An epidemiological study in Hong Kong showed differences between boys and girls concerning the type of $\mathrm{AP}$ and window time, which was related to later pubertal development, and the results were based on multipollutant analysis. ${ }^{67)}$ Higher $\mathrm{PM}_{10}$ exposure in utero and in infancy lowered the pubertal stage among girls, whereas higher $\mathrm{SO}_{2}$ and $\mathrm{NO}_{2}$ exposure in utero and during childhood lowered the pubertal stage among boys. In contrast, girls that lived within $150 \mathrm{~m}$ from major roads or highways developed pubic hair several months earlier than those that lived further away. ${ }^{68)}$ Moreover, exposure to a higher concentration of $\mathrm{PM}_{10}$ in the pre-menarche period was associated with lower menarche age in Korean adolescents, and the risk of early menarche was higher when the exposure period was shorter, indicating that the neuroendocrine system becomes susceptible to PM10 exposure at the time of menarche.69) However, no relationship between air pollutants $\left(\mathrm{NO}_{2}, \mathrm{O}_{3}, \mathrm{PM}_{10}\right.$, and $\left.\mathrm{PM}_{2.5}\right)$ and serum sex hormone levels in 10-year-old children was reported. ${ }^{70)}$

Table 4. Human studies investigating the relationship of ambient air pollution and thyroid dysfunction

\begin{tabular}{|c|c|c|c|c|c|c|c|}
\hline Country & Study design & Subjects & Exposure & Exposure period & Outcome & Findings & Study \\
\hline \multicolumn{8}{|l|}{ Prenatal } \\
\hline Belgium & Cohort & $\begin{array}{c}499 \text { Mother and } \\
\text { newborn pairs }\end{array}$ & $\mathrm{PM}_{2.5}$ & Third trimester & $\begin{array}{l}\text { TFT of mother } \\
\text { and infant }\end{array}$ & $\begin{array}{l}\text { Decrease in cord blood TSH level and } \\
\text { cord blood fT4/fT3 ratio }\end{array}$ & Janssen, ${ }^{60)} 2017$ \\
\hline USA & Cohort & 2050 Newborns & $\begin{array}{l}\mathrm{NO}, \mathrm{NO}_{2}, \mathrm{O}_{3,} \\
\mathrm{PM}_{10,} \mathrm{PM}_{2.5}\end{array}$ & Prenatal & $\begin{array}{l}\text { Total T4 levels of } \\
\text { newborn }\end{array}$ & $\begin{array}{l}\mathrm{PM}_{2.5} \text { and } \mathrm{PM} 10 \text { was associated with } \\
\text { an increase in total T4 levels of heel- } \\
\text { stick blood spot (not } \mathrm{NO}_{1} \mathrm{NO}_{2}, \mathrm{O}_{3} \text { ). }\end{array}$ & Howe, $^{611} 2018$ \\
\hline China & Cohort & $\begin{array}{l}443 \text { Mother and } \\
\text { newborn pairs }\end{array}$ & $\mathrm{PM}_{2.5}$ & First trimester & $\begin{array}{l}\text { TFT of mother } \\
\text { and infant }\end{array}$ & Not associated with neonatal TSH & Wang, 2019 \\
\hline China & Cross-sectional & $\begin{array}{l}\text { 15.1 Million } \\
\text { newborns }\end{array}$ & $\mathrm{PM}_{10,}, \mathrm{PM}_{2.5}$ & Prenatal & $\begin{array}{l}\text { Congenital } \\
\text { hypothyroidism }\end{array}$ & $\begin{array}{l}\text { PM }_{2.5} \text { was associated with an } \\
\text { increased risk of congenital } \\
\text { hypothyroidism (not PM10). }\end{array}$ & Shang, ${ }^{63)} 2019$ \\
\hline
\end{tabular}

PM2.5, particulate matter with an aerodynamic diameter of $<2.5 \mu \mathrm{m}$; TFT, thyroid function test; TSH, thyroid-stimulating hormone; fT4, free thyroxine; fT3, free triiodothyronine; $\mathrm{NO}$, nitric oxide; $\mathrm{NO}_{2}$, nitrogen dioxide; $\mathrm{O}_{3}$, ozone; $\mathrm{PM}_{10}$, particulate matter with an aerodynamic diameter of $<10 \mu \mathrm{m}$. 
Table 5. Human studies investigating the relationship of ambient air pollution and pubertal development

\begin{tabular}{|c|c|c|c|c|c|c|c|}
\hline Country & Study design & Subjects (age) & Pollutants & $\begin{array}{l}\text { Exposure periods } \\
\text { (age) }\end{array}$ & Outcome (age) & Findings & Study \\
\hline \multicolumn{8}{|l|}{ Prenatal } \\
\hline Hong Kong & Cohort & $\begin{array}{l}\text { 1,938 Girls and } \\
\text { 2,316 boys }\end{array}$ & $\begin{array}{l}\mathrm{NO}, \mathrm{NO}_{2}, \mathrm{SO}_{2} \\
\quad \mathrm{PM}_{10}\end{array}$ & In utero & $\begin{array}{l}\text { Tanner stage } \\
\text { (9-12 years old) }\end{array}$ & $\begin{array}{l}\text { Higher } \mathrm{PM}_{10} \text { exposure in utero and in } \\
\text { infancy was associated with later } \\
\text { pubertal development among girls. } \\
\text { Higher } \mathrm{SO}_{2} \text { and } \mathrm{NO}_{2} \text { exposure in in- } \\
\text { fancy and childhood were associated } \\
\text { with later pubertal development } \\
\text { among boys. }\end{array}$ & $\begin{array}{l}\text { Huang, } \\
2017\end{array}$ \\
\hline \multicolumn{8}{|l|}{ Postnatal } \\
\hline USA & Cohort & $\begin{array}{l}437 \text { Girls } \\
\text { (6-8 years old) }\end{array}$ & $\begin{array}{l}\text { Traffic density, } \\
\text { roadway } \\
\text { proximity }\end{array}$ & $\begin{array}{l}\text { 9-Year annual } \\
\text { average levels }\end{array}$ & $\begin{array}{l}\text { Tanner stage } \\
\text { (6-8 years old })\end{array}$ & $\begin{array}{l}\text { Associated with earlier onset (2-9 } \\
\text { months) of pubic hair development } \\
\text { (not breast development) }\end{array}$ & $\begin{array}{l}\text { McGuinn, } \\
2016\end{array}$ \\
\hline Hong Kong & Cohort & $\begin{array}{l}\text { 1,938 Girls and } \\
\text { 2,316 boys }\end{array}$ & $\begin{array}{l}\mathrm{NO}, \mathrm{NO}_{2}, \mathrm{SO}_{2} \\
\quad \mathrm{PM}_{10}\end{array}$ & $\begin{array}{c}\text { In infancy }(<2 \\
\text { years) and in } \\
\text { childhood }(2-<8 \\
\text { years })\end{array}$ & $\begin{array}{l}\text { Tanner stage } \\
\text { (9-12 years old })\end{array}$ & $\begin{array}{l}\text { Higher } \mathrm{PM}_{10} \text { exposure in utero and in } \\
\text { infancy was associated with later } \\
\text { pubertal development among girls. } \\
\text { Higher } \mathrm{SO}_{2} \text { and } \mathrm{NO}_{2} \text { exposure in in- } \\
\text { fancy and childhood were associated } \\
\text { with later pubertal development } \\
\text { among boys. }\end{array}$ & $\begin{array}{l}\text { Huang, } \\
2017\end{array}$ \\
\hline Korea & $\begin{array}{l}\text { Cross- } \\
\text { sectional }\end{array}$ & $\begin{array}{l}639 \text { Girls } \\
\text { (13-17 years } \\
\text { old) }\end{array}$ & $\mathrm{PM}_{10}$ & $\begin{array}{l}1 \text { to 3-year annual } \\
\text { average level }\end{array}$ & Age at menarche & $\begin{array}{l}\text { Associated with earlier onset of age at } \\
\text { menarche }\end{array}$ & $\begin{array}{l}\text { Jung, }_{1}{ }^{99} \\
2018\end{array}$ \\
\hline German & Cohort & $\begin{array}{l}943 \text { Girls and } \\
1,002 \text { boys }\end{array}$ & $\begin{array}{l}\mathrm{NO}_{2}, \mathrm{O}_{3}, \mathrm{PM}_{10} \\
\quad \mathrm{PM}_{2.5}\end{array}$ & $\begin{array}{l}\text { 5-Year annual } \\
\text { average levels }\end{array}$ & $\begin{array}{c}\text { Serum estradiol } \\
\text { and testosterone } \\
\text { levels } \\
\text { (at } 10 \text { years old) }\end{array}$ & $\begin{array}{l}\text { Not associated with pubertal develop- } \\
\text { ment defined by levels of estradiol } \\
\text { and testosterone }\end{array}$ & $\begin{array}{c}\text { Zhao, }^{70)} \\
2021\end{array}$ \\
\hline
\end{tabular}

$\mathrm{NO}$, nitric oxide; $\mathrm{NO}_{2}$, nitrogen dioxide; $\mathrm{SO}_{2}$, sulfur dioxide; $\mathrm{PM} 10$, particulate matter with an aerodynamic diameter of $<10 \mu \mathrm{m}$.

\section{Possible mechanisms}

\section{The immune system and inflammatory responses}

The mechanism by which air pollutants contribute to endocrinologic disorders is not known, although altered immune responses and inflammatory reactions have been suggested as possibilities. ${ }^{71)}$ Inhaled AP comes into contact with alveolar macrophages and induces proinflammatory cytokine production as well as oxidative stress. These cytokines can spill over into systemic circulation and affect distant tissues, promoting autoimmune responses and metabolic dysfunction. ${ }^{71)}$ PM components such as transition metals, lipopolysaccharides, and $\mathrm{O}_{3}$ can infiltrate into the systemic vasculature and activate toll-like receptors. ${ }^{72)}$ Signal transduction, including transcription factor nuclear factor kappa B, is activated and promotes the production of proinflammatory cytokines (interleukin [IL]-4, IL-6, IL-8, and tumor necrosis factor [TNF]- $\alpha),{ }^{73,74)}$ which leads to chronic inflammation and low-grade oxidative stress in the body. Particularly, $\mathrm{PM}_{2.5}$ modulates cytokine production and changes the balance between TNF- $\alpha$ and the production of antiinflammatory IL-10 molecules in adolescents. ${ }^{75)}$ Increased IL10 and reduced TNF- $\alpha$ levels serve as a biomarker for T helper 1 cell-mediated immune suppression and exacerbation of $\mathrm{T}$ helper 2-mediated humoral immune responses, contributing to the development of autoimmune diseases such as T1DM.

\section{The neuroendocrine system}

The neuroendocrine system can be important in APinduced endocrine dysfunction. An experimental study revealed that exposure to prenatal diesel exhaust induced direct neuroinflammation and neuronal structural changes in the feeding centers of the hypothalamus and increased vulnerability to a high-fat diet and weight gain later in life, ${ }^{76)}$ suggesting direct alteration of the central nervous system. AP also can activate stress-responsive regions in the brain through the sympathetic efferent and the hypothalamus-pituitary-adrenal axes. ${ }^{77)}$ For example, $\mathrm{O}_{3}$ inhalation evokes lung inflammation that induces the activation of nucleus tractus solitarius neurons through the vagus nerves and promotes neuronal activation in stressresponsive regions of the central nervous system in mice. ${ }^{78)} \mathrm{O}_{3}$ exposure also increased circulating corticosterone and cortisol levels in humans. ${ }^{79)}$ These results show that increased neuronal stress response can affect metabolic regulation.

\section{Placental development and epigenetic modulation}

Environmental stimuli or challenges during critical periods can alter placental development to the extent that the placenta could adapt by alternating transporter expression and activity to maintain fetal growth or by epigenetic regulation of placental gene expression, resulting in detrimental consequences later in life. ${ }^{80)}$ Inadequate placental perfusion affects fetal growth of 
the endocrine system in utero. AP exposure during pregnancy contributes to an anti-angiogenic profile, which could decrease placental weight ${ }^{81)}$ and is associated with increased inflammatory markers. ${ }^{82,83}$

The epigenetic repression and activation of gene transcription are affected by environmental stimuli, such as nutrition, light, and endocrine disruptors. ${ }^{84)}$ There is increasing evidence that epigenetic mechanisms play an important role in the development of $\mathrm{T} \mathrm{DM}^{85,86}$ and also in neuroendocrine system regulation, which can impact the timing of puberty ${ }^{84,87)}$ In addition, a recent study showed that in utero exposure to polycyclic aromatic hydrocarbons induces offspring obesity by hypomethylation of peroxisome proliferator-activated receptorgamma and by subsequent activation of various genes associated with adipogenesis in adipose tissue of the offspring. Exposure to PM also induces deoxyribonucleic acid methylation, ${ }^{88)}$ which could be a partial mediator between PM and adverse health outcomes.

\section{Obesity and insulin resistance}

The effects of increased AP exposure on the development of obesity and insulin resistance are complex and multifactorial. Excess AP is associated with decreased outdoor activities and reduced energy expenditure, which increases the likelihood of obesity. Alternations in mitochondrial number and size, downregulated brown adipocyte-specific genes in thermogenesis, and energy expenditure also are induced by PM exposure ${ }^{89)}$ In addition, exposure to AP can alter the basal metabolism, including white adipose tissue inflammation, inhibition of lipolysis, and redistribution of adipose tissue in the viscera, ${ }^{89-92)}$ playing a key role in the development of insulin resistance, diabetes, and systemic inflammatory effects. Endothelial dysfunction after AP exposure ${ }^{93,94)}$ is implicated in reduced peripheral glucose uptake. $\mathrm{O}_{3}$ also creates free oxygen radicals that directly contribute to beta-cell damage. ${ }^{95)}$

\section{Thyroid system}

Research has indicated that oxidative stress, inflammatory status, alterations to the neuroendocrine system, and inadequate placental adaptation can affect the thyroid. For example, increased glucocorticoid activity markers inhibit TSH release. Increased thyroid-binding globulin was observed after exposure to cigarette smoke, which could be transferred via the placenta, and can lead to higher total T4 level and lower free T4 level. ${ }^{96}$ ) Cigarette smoke was associated with stimulated conversion of $\mathrm{T} 4$ to $\mathrm{T} 3$ by activities that promoted type 2 deiodinase in tissues, leading to decreased free T4 level and increased free T3 level. ${ }^{97)}$ A recent experimental study in female rats found that $\mathrm{PM}_{2.5}$ exposure could reduce circulating thyroid hormone levels by interrupting thyroid hormone biosynthesis, biotransformation, and transport; inducing oxidative stress and inflammatory responses; and ultimately activating the hypothalamicpituitary-thyroid axis and inducing the production of hepatic transthyretin. $^{98)}$

\section{Pubertal development}

The mechanisms that link AP and pubertal development or sex hormones have not been investigated, although they are expected to mimic the effects of EDCs. These effects could be caused by several mechanisms that impact puberty either peripherally or centrally; the agents could act as agonists of estrogen receptors or antagonists of androgen receptors and as obesogens, which alter the metabolic and peripheral hormones and can affect genes or the hypothalamic-pituitary-gonad axis. ${ }^{99)}$

\section{Conclusion}

Human studies provide considerable evidence of shortand long-term exposures to ambient APs, such as PM, $\mathrm{NO}_{2}$, and $\mathrm{NO}_{\mathrm{x}}$, which affect the endocrine system and contribute to the development of childhood T1DM, obesity, and insulin resistance, although conflicting results have been reported. However, there is little evidence on the effect on thyroid function on onset of puberty. Altered immune response, oxidative stress, neuroinflammation, inadequate placental development, and epigenetic modulation are some of the underlying factors that have been identified and investigated. However, it is difficult to demonstrate causality because results from human studies are heterogeneous due to different study designs, timing and degree of exposure, methodology of exposure, and outcome measurements. Additionally, ambient APs are composed of various microscopic solids or liquid droplets and EDCs, and the extent to which airborne EDCs contribute to the overall burden on the human body is unknown. To further understand the mechanisms that link AP and the risk of endocrine disorders in children, future studies should consider the multipollutant nature of the mixture and the varying chemical composition, which could lead to different toxicities according to sex or susceptible window. Studies on additional outcomes such as changes in metabolomics and the microbiome in the intestine and central nervous system are needed to evaluate the biological pathway. Future research can help prevent environmental toxicity and improve treatment approaches for endocrine disorders.

\section{Conflicts of interest}

No potential conflict of interest relevant to this article was reported.

\section{References}

1. Cohen AJ, Brauer M, Burnett R, Anderson HR, Frostad J, Estep K, et al. Estimates and 25-year trends of the global burden of disease attributable to ambient air pollution: An analysis of data from the global burden of diseases study 
2015. Lancet 2017;389:1907-18.

2. Badyda A, Gayer A, Czechowski PO, Majewski G, Dąbrowiecki P. Pulmonary function and incidence of selected respiratory diseases depending on the exposure to ambient pm(10). Int J Mol Sci 2016;17:1954.

3. Baldacci S, Maio S, Cerrai S, Sarno G, Baïz N, Simoni M, et al. Allergy and asthma: effects of the exposure to particulate matter and biological allergens. Respir Med 2015;109:1089104.

4. Renzi M, Cerza F, Gariazzo C, Agabiti N, Cascini S, Di Domenicantonio R, et al. Air pollution and occurrence of type 2 diabetes in a large cohort study. Environ Int 2018;112:68-76.

5. Brook RD, Bard RL, Morishita M, Dvonch JT, Wang L, Yang $\mathrm{HY}$, et al. Hemodynamic, autonomic, and vascular effects of exposure to coarse particulate matter air pollution from a rural location. Environ Health Perspect 2014;122:624-30.

6. Darbre PD. Overview of air pollution and endocrine disorders. Int J Gen Med 2018;11:191-207.

7. Vehik K, Dabelea D. The changing epidemiology of type 1 diabetes: why is it going through the roof? Diabetes Metab Res Rev 2011;27:3-13.

8. Howard SG. Exposure to environmental chemicals and type 1 diabetes: an update. J Epidemiol Community Health 2019;73:483-8.

9. Hathout EH, Beeson WL, Ischander M, Rao R, Mace JW. Air pollution and type 1 diabetes in children. Pediatr Diabetes 2006;7:81-7.

10. Hathout EH, Beeson WL, Nahab F, Rabadi A, Thomas W, Mace JW. Role of exposure to air pollutants in the development of type 1 diabetes before and after $5 \mathrm{yr}$ of age. Pediatr Diabetes 2002;3:184-8.

11. Malmqvist E, Larsson HE, Jönsson I, Rignell-Hydbom A, Ivarsson SA, Tinnerberg $\mathrm{H}$, et al. Maternal exposure to air pollution and type 1 diabetes--accounting for genetic factors. Environ Res 2015;140:268-74.

12. Elten M, Donelle J, Lima I, Burnett RT, Weichenthal S, Stieb DM, et al. Ambient air pollution and incidence of earlyonset paediatric type 1 diabetes: a retrospective populationbased cohort study. Environ Res 2020;184:109291.

13. Taha-Khalde A, Haim A, Karakis I, Shashar S, Biederko R, Shtein A, et al. Air pollution and meteorological conditions during gestation and type 1 diabetes in offspring. Environ Int 2021;154:106546.

14. Beyerlein A, Krasmann M, Thiering E, Kusian D, Markevych I, D'Orlando O, et al. Ambient air pollution and early manifestation of type 1 diabetes. Epidemiology 2015;26:e31-2.

15. Di Ciaula A. Type i diabetes in paediatric age in apulia (italy): incidence and associations with outdoor air pollutants. Diabetes Res Clin Pract 2016;111:36-43.

16. Rosenbauer J, Tamayo T, Bächle C, Stahl-Pehe A, Landwehr S, Sugiri D, et al. Re: Ambient air pollution and early manifestation of type 1 diabetes. Epidemiology 2016;27:e25-6.

17. Tamayo T, Rathmann W, Stahl-Pehe A, Landwehr S, Sugiri D,
Krämer U, et al. No adverse effect of outdoor air pollution on hbalc in children and young adults with type 1 diabetes. Int J Hyg Environ Health 2016;219:349-55.

18. Lanzinger S, Rosenbauer J, Sugiri D, Schikowski T, Treiber $\mathrm{B}$, Klee D, et al. Impact of long-term air pollution exposure on metabolic control in children and adolescents with type 1 diabetes: results from the dpv registry. Diabetologia 2018;61:1354-61.

19. Michalska M, Zorena K, Wąż P, Bartoszewicz M, BrandtVarma A, Ślęzak D, et al. Gaseous pollutants and particulate matter $(\mathrm{pm})$ in ambient air and the number of new cases of type 1 diabetes in children and adolescents in the pomeranian voivodeship, poland. Biomed Res Int 2020;2020:1648264.

20. Sagai M, Bocci V. Mechanisms of action involved in ozone therapy: is healing induced via a mild oxidative stress? Med Gas Res 2011;1:29.

21. Holtcamp W. Obesogens: an environmental link to obesity. Environ Health Perspect 2012;120:a62-8.

22. Rundle A, Hoepner L, Hassoun A, Oberfield S, Freyer G, Holmes D, et al. Association of childhood obesity with maternal exposure to ambient air polycyclic aromatic hydrocarbons during pregnancy. Am J Epidemiol 2012;175:1163-72.

23. Ino T, Shibuya T, Saito K, Inaba Y. Relationship between body mass index of offspring and maternal smoking during pregnancy. Int J Obes (Lond) 2012;36:554-8.

24. Fleisch AF, Rifas-Shiman SL, Koutrakis P, Schwartz JD, Kloog I, Melly S, et al. Prenatal exposure to traffic pollution: associations with reduced fetal growth and rapid infant weight gain. Epidemiology 2015;26:43-50.

25. Fleisch AF, Luttmann-Gibson H, Perng W, Rifas-Shiman SL, Coull BA, Kloog I, et al. Prenatal and early life exposure to traffic pollution and cardiometabolic health in childhood. Pediatr Obes 2017;12:48-57.

26. Mao G, Nachman RM, Sun Q, Zhang X, Koehler K, Chen Z, et al. Individual and joint effects of early-life ambient exposure and maternal prepregnancy obesity on childhood overweight or obesity. Environ Health Perspect 2017;125:067005.

27. Chiu YM, Hsu HL, Wilson A, Coull BA, Pendo MP, Baccarelli A, et al. Prenatal particulate air pollution exposure and body composition in urban preschool children: examining sensitive windows and sex-specific associations. Environ Res 2017;158:798-805.

28. Kim JS, Alderete TL, Chen Z, Lurmann F, Rappaport E, Habre R, et al. Longitudinal associations of in utero and early life near-roadway air pollution with trajectories of childhood body mass index. Environ Health 2018;17:64.

29. Fleisch AF, Aris IM, Rifas-Shiman SL, Coull BA, LuttmannGibson H, Koutrakis P, et al. Prenatal exposure to traffic pollution and childhood body mass index trajectory. Front Endocrinol (Lausanne) 2018;9:771.

30. Huang JV, Leung GM, Schooling CM. The association of air pollution with body mass index: evidence from hong kong's "children of 1997" birth cohort. Int J Obes (Lond) 
2019;43:62-72.

31. Jerrett M, McConnell R, Chang CC, Wolch J, Reynolds K, Lurmann F, et al. Automobile traffic around the home and attained body mass index: a longitudinal cohort study of children aged 10-18 years. Prev Med 2010;50 Suppl 1:S50-8.

32. Jerrett M, McConnell R, Wolch J, Chang R, Lam C, Dunton $\mathrm{G}$, et al. Traffic-related air pollution and obesity formation in children: a longitudinal, multilevel analysis. Environ Health 2014;13:49.

33. McConnell R, Shen E, Gilliland FD, Jerrett M, Wolch J, Chang CC, et al. A longitudinal cohort study of body mass index and childhood exposure to secondhand tobacco smoke and air pollution: the southern california children's health study. Environ Health Perspect 2015;123:360-6.

34. Alderete TL, Habre R, Toledo-Corral CM, Berhane K, Chen Z, Lurmann FW, et al. Longitudinal associations between ambient air pollution with insulin sensitivity, $\beta$-cell function, and adiposity in los angeles latino children. Diabetes 2017;66:1789-96.

35. Dong GH, Qian Z, Liu MM, Wang D, Ren WH, Flick LH, et al. Ambient air pollution and the prevalence of obesity in Chinese children: the seven northeastern cities study. Obesity 2014;22:795-800.

36. Bloemsma LD, Wijga AH, Klompmaker JO, Janssen NAH, Smit HA, Koppelman GH, et al. The associations of air pollution, traffic noise and green space with overweight throughout childhood: the PIAMA birth cohort study. Environ Res 2019;169:348-56.

37. De Bont J, Casas M, Barrera-Gómez J, Cirach M, Rivas I, Valvi D, et al. Ambient air pollution and overweight and obesity in school-aged children in barcelona, spain. Environ Int 2019;125:58-64.

38. Guo Q, Xue T, Jia C, Wang B, Cao S, Zhao X, et al. Association between exposure to fine particulate matter and obesity in children: a national representative crosssectional study in China. Environ Int 2020;143:105950.

39. Zheng H, Xu Z, Wang Q, Ding Z, Zhou L, Xu Y, et al. Longterm exposure to ambient air pollution and obesity in school-aged children and adolescents in Jiangsu province of China. Environ Res 2021;195:110804.

40. Zhang Z, Dong B, Chen G, Song Y, Li S, Yang Z, et al. Ambient air pollution and obesity in school-aged children and adolescents: A multicenter study in China. Sci Total Environ 2021;771:144583.

41. De Bont J, Díaz Y, de Castro M, Cirach M, Basagaña X, Nieuwenhuijsen M, et al. Ambient air pollution and the development of overweight and obesity in children: a large longitudinal study. Int J Obes (Lond) 2021;45:1124-32.

42. Fioravanti S, Cesaroni G, Badaloni C, Michelozzi P, Forastiere F, Porta D. Traffic-related air pollution and childhood obesity in an italian birth cohort. Environ Res 2018;160:479-86.

43. Global, regional, and national incidence, prevalence, and years lived with disability for 310 diseases and injuries, 1990-2015: a systematic analysis for the global burden of disease study 2015. Lancet 2016;388:1545-602.
44. Balti EV, Echouffo-Tcheugui JB, Yako YY, Kengne AP. Air pollution and risk of type 2 diabetes mellitus: a systematic review and meta-analysis. Diabetes Res Clin Pract 2014;106:161-72.

45. Liu F, Chen G, Huo W, Wang C, Liu S, Li N, et al. Associations between long-term exposure to ambient air pollution and risk of type 2 diabetes mellitus: a systematic review and meta-analysis. Environ Pollut 2019;252:123545.

46. Yang BY, Fan S, Thiering E, Seissler J, Nowak D, Dong GH, et al. Ambient air pollution and diabetes: a systematic review and meta-analysis. Environ Res 2020;180:108817.

47. Eze IC, Hemkens LG, Bucher HC, Hoffmann B, Schindler C, Künzli N, et al. Association between ambient air pollution and diabetes mellitus in Europe and north America: systematic review and meta-analysis. Environ Health Perspect 2015;123:381-9.

48. Madhloum N, Janssen BG, Martens DS, Saenen ND, Bijnens E, Gyselaers W, et al. Cord plasma insulin and in utero exposure to ambient air pollution. Environ Int 2017;105:126-32.

49. Moody EC, Cantoral A, Tamayo-Ortiz M, Pizano-Zárate ML, Schnaas L, Kloog I, et al. Association of prenatal and perinatal exposures to particulate matter with changes in hemoglobin alc levels in children aged 4 to 6 years. JAMA Netw Open 2019;2:e1917643.

50. Pedersen M, Halldorsson TI, Ketzel M, Grandström C, Raaschou-Nielsen O, Jensen SS, et al. Associations between ambient air pollution and noise from road traffic with blood pressure and insulin resistance in children from Denmark. Environ Epidemiol 2019;3:e069.

51. Thiering E, Cyrys J, Kratzsch J, Meisinger C, Hoffmann B, Berdel D, et al. Long-term exposure to traffic-related air pollution and insulin resistance in children: results from the GINIplus and LISAplus birth cohorts. Diabetologia 2013;56:1696-704.

52. Thiering E, Markevych I, Brüske I, Fuertes E, Kratzsch J, Sugiri D, et al. Associations of residential long-term air pollution exposures and satellite-derived greenness with insulin resistance in German adolescents. Environ Health Perspect 2016;124:1291-8.

53. Toledo-Corral CM, Alderete TL, Habre R, Berhane K, Lurmann FW, Weigensberg MJ, et al. Effects of air pollution exposure on glucose metabolism in los angeles minority children. Pediatr Obes 2018;13:54-62.

54. Zhang JS, Gui ZH, Zou ZY, Yang BY, Ma J, Jing J, et al. Longterm exposure to ambient air pollution and metabolic syndrome in children and adolescents: a national crosssectional study in china. Environ Int 2021;148:106383.

55. Ghosh R, Gauderman WJ, Minor H, Youn HA, Lurmann F, Cromar KR, et al. Air pollution, weight loss and metabolic benefits of bariatric surgery: a potential model for study of metabolic effects of environmental exposures. Pediatr Obes 2018;13:312-20.

56. Gore AC, Chappell VA, Fenton SE, Flaws JA, Nadal A, Prins GS, et al. Edc-2: the endocrine society's second scientific 
statement on endocrine-disrupting chemicals. Endocr Rev 2015;36:E1-150.

57. Abdelouahab N, Langlois MF, Lavoie L, Corbin F, Pasquier JC, Takser L. Maternal and cord-blood thyroid hormone levels and exposure to polybrominated diphenyl ethers and polychlorinated biphenyls during early pregnancy. Am J Epidemiol 2013;178:701-13.

58. Iijima K, Otake T, Yoshinaga J, Ikegami M, Suzuki E, Naruse $\mathrm{H}$, et al. Cadmium, lead, and selenium in cord blood and thyroid hormone status of newborns. Biol Trace Elem Res 2007;119:10-8.

59. Soldin OP, Goughenour BE, Gilbert SZ, Landy HJ, Soldin SJ. Thyroid hormone levels associated with active and passive cigarette smoking. Thyroid 2009;19:817-23.

60. Janssen BG, Saenen ND, Roels HA, Madhloum N, Gyselaers W, Lefebvre W, et al. Fetal thyroid function, birth weight, and in utero exposure to fine particle air pollution: a birth cohort study. Environ Health Perspect 2017;125:699-705.

61. Howe CG, Eckel SP, Habre R, Girguis MS, Gao L, Lurmann FW, et al. Association of prenatal exposure to ambient and traffic-related air pollution with newborn thyroid function: findings from the children's health study. JAMA Netw Open 2018;1:e182172.

62. Wang X, Liu C, Zhang M, Han Y, Aase H, Villanger GD, et al. Evaluation of maternal exposure to $\mathrm{pm}(2.5)$ and its components on maternal and neonatal thyroid function and birth weight: a cohort study. Thyroid 2019;29:1147-57.

63. Shang L, Huang L, Yang W, Qi C, Yang L, Xin J, et al. Maternal exposure to $\operatorname{PM}(2.5)$ may increase the risk of congenital hypothyroidism in the offspring: a national database based study in China. BMC Public Health 2019;19:1412.

64. Parent AS, Franssen D, Fudvoye J, Gérard A, Bourguignon JP. Developmental variations in environmental influences including endocrine disruptors on pubertal timing and neuroendocrine control: revision of human observations and mechanistic insight from rodents. Front Neuroendocrinol 2015;38:12-36.

65. Maisonet M, Christensen KY, Rubin C, Holmes A, Flanders WD, Heron J, et al. Role of prenatal characteristics and early growth on pubertal attainment of British girls. Pediatrics 2010;126:e591-600.

66. Windham GC, Lum R, Voss R, Wolff M, Pinney SM, Teteilbaum SL, et al. Age at pubertal onset in girls and tobacco smoke exposure during pre- and postnatal susceptibility windows. Epidemiology 2017;28:719-27.

67. Huang JV, Leung GM, Schooling CM. The association of air pollution with pubertal development: Evidence from Hong Kong's "children of 1997" birth cohort. Am J Epidemiol 2017;185:914-23.

68. McGuinn LA, Voss RW, Laurent CA, Greenspan LC, Kushi LH, Windham GC. Residential proximity to traffic and female pubertal development. Environ Int 2016;94:635-41.

69. Jung EM, Kim HS, Park H, Ye S, Lee D, Ha EH. Does exposure to $\mathrm{PM}(10)$ decrease age at menarche? Environ Int 2018;117:16-21.

70. Zhao T, Triebner K, Markevych I, Standl M, Altug H, de
Hoogh K, et al. Outdoor air pollution and hormoneassessed pubertal development in children: results from the GINIplus and LISA birth cohorts. Environ Int 2021;152:106476.

71. Ritz SA. Air pollution as a potential contributor to the 'epidemic' of autoimmune disease. Med Hypotheses 2010;74:110-7.

72. Li Z, Potts-Kant EN, Garantziotis S, Foster WM, Hollingsworth JW. Hyaluronan signaling during ozoneinduced lung injury requires $\operatorname{tr} 4$, myd88, and tirap. PLoS One 2011;6:e27137.

73. Mirowsky JE, Carraway MS, Dhingra R, Tong H, Neas L, Diaz-Sanchez D, et al. Ozone exposure is associated with acute changes in inflammation, fibrinolysis, and endothelial cell function in coronary artery disease patients. Environ Health 2017;16:126.

74. Pilz V, Wolf K, Breitner S, Rückerl R, Koenig W, Rathmann W, et al. C-reactive protein (crp) and long-term air pollution with a focus on ultrafine particles. Int J Hyg Environ Health 2018;221:510-8.

75. Dobreva ZG, Kostadinova GS, Popov BN, Petkov GS, Stanilova SA. Proinflammatory and anti-inflammatory cytokines in adolescents from southeast bulgarian cities with different levels of air pollution. Toxicol Ind Health 2015;31:1210-7.

76. Bolton JL, Smith SH, Huff NC, Gilmour MI, Foster WM, Auten RL, et al. Prenatal air pollution exposure induces neuroinflammation and predisposes offspring to weight gain in adulthood in a sex-specific manner. FASEB J 2012;26:4743-54.

77. Kodavanti UP. Stretching the stress boundary: linking air pollution health effects to a neurohormonal stress response. Biochim Biophys Acta 2016;1860:2880-90.

78. Gackière F, Saliba L, Baude A, Bosler O, Strube C. Ozone inhalation activates stress-responsive regions of the cns. J Neurochem 2011;117:961-72.

79. Miller DB, Ghio AJ, Karoly ED, Bell LN, Snow SJ, Madden $\mathrm{MC}$, et al. Ozone exposure increases circulating stress hormones and lipid metabolites in humans. Am J Respir Crit Care Med 2016;193:1382-91.

80. Yan Z, Zhang H, Maher C, Arteaga-Solis E, Champagne FA, Wu L, et al. Prenatal polycyclic aromatic hydrocarbon, adiposity, peroxisome proliferator-activated receptor (ppar) $\gamma$ methylation in offspring, grand-offspring mice. PLoS One 2014;9:e110706.

81. van den Hooven EH, Pierik FH, de Kluizenaar Y, Hofman A, van Ratingen SW, Zandveld PY, et al. Air pollution exposure and markers of placental growth and function: the generation r study. Environ Health Perspect 2012;120:17539.

82. Lee PC, Talbott EO, Roberts JM, Catov JM, Sharma RK, Ritz B. Particulate air pollution exposure and c-reactive protein during early pregnancy. Epidemiology 2011;22:524-31.

83. Vadillo-Ortega F, Osornio-Vargas A, Buxton MA, Sánchez BN, Rojas-Bracho L, Viveros-Alcaráz M, et al. Air pollution, inflammation and preterm birth: a potential mechanistic 
link. Med Hypotheses 2014;82:219-24.

84. Lomniczi A, Wright H, Ojeda SR. Epigenetic regulation of female puberty. Front Neuroendocrinol 2015;36:90-107.

85. Zhao CN, Xu Z, Wu GC, Mao YM, Liu LN, Qian W, et al. Emerging role of air pollution in autoimmune diseases. Autoimmun Rev 2019;18:607-14.

86. Cerna M. Epigenetic regulation in etiology of type 1 diabetes mellitus. Int J Mol Sci 2019;21:36.

87. Rzeczkowska PA, Hou H, Wilson MD, Palmert MR. Epigenetics: a new player in the regulation of mammalian puberty. Neuroendocrinology 2014;99:139-55.

88. Sun B, Shi Y, Yang X, Zhao T, Duan J, Sun Z. DNA methylation: a critical epigenetic mechanism underlying the detrimental effects of airborne particulate matter. Ecotoxicol Environ Saf 2018;161:173-83.

89. Xu Z, Xu X, Zhong M, Hotchkiss IP, Lewandowski RP, Wagner JG, et al. Ambient particulate air pollution induces oxidative stress and alterations of mitochondria and gene expression in brown and white adipose tissues. Part Fibre Toxicol 2011;8:20.

90. Sun Q, Yue P, Deiuliis JA, Lumeng CN, Kampfrath T, Mikolaj MB, et al. Ambient air pollution exaggerates adipose inflammation and insulin resistance in a mouse model of diet-induced obesity. Circulation 2009;119:53846.

91. Irigaray P, Ogier V, Jacquenet S, Notet V, Sibille P, Méjean L, et al. Benzo[a]pyrene impairs beta-adrenergic stimulation of adipose tissue lipolysis and causes weight gain in mice. A novel molecular mechanism of toxicity for a common food pollutant. FEBS J 2006;273:1362-72.
92. Zou MH. Is nad(p)h oxidase a missing link for air pollution-enhanced obesity? Arterioscler Thromb Vasc Biol 2010;30:2323-4.

93. Mills NL, Törnqvist H, Robinson SD, Gonzalez M, Darnley K, MacNee W, et al. Diesel exhaust inhalation causes vascular dysfunction and impaired endogenous fibrinolysis. Circulation 2005; 112:3930-6.

94. Sun Q, Wang A, Jin X, Natanzon A, Duquaine D, Brook RD, et al. Long-term air pollution exposure and acceleration of atherosclerosis and vascular inflammation in an animal model. JAMA 2005;294:3003-10.

95. Butalia S, Kaplan GG, Khokhar B, Rabi DM. Environmental risk factors and type 1 diabetes: past, present, and future. Can J Diabetes 2016;40:586-93.

96. Fisher CL, Mannino DM, Herman WH, Frumkin H. Cigarette smoking and thyroid hormone levels in males. Int J Epidemiol 1997;26:972-7.

97. Gondou A, Toyoda N, Nishikawa M, Yonemoto T, Sakaguchi N, Tokoro T, et al. Effect of nicotine on type 2 deiodinase activity in cultured rat glial cells. Endocr J 1999;46:107-12.

98. Dong X, Wu W, Yao S, Li H, Li Z, Zhang L, et al. PM(2.5) disrupts thyroid hormone homeostasis through activation of the hypothalamic-pituitary-thyroid (HPT) axis and induction of hepatic transthyretin in female rats 2.5. Ecotoxicol Environ Saf 2021;208:111720.

99. Lee JE, Jung HW, Lee YJ, Lee YA. Early-life exposure to endocrine-disrupting chemicals and pubertal development in girls. Ann Pediatr Endocrinol Metab 2019;24:78-91. 